\title{
SWOT-TOWS ANALYSIS AS A PLANNING TOOL OF PROCESS IMPROVEMENT BASED ON PDCA CYCLE IN SERVICE EN- TERPRISE
}

\begin{abstract}
The aim of this paper is to carry out a SWOT-TOWS analysis for a service enterprises - the chosen cinema. The SWOT analysis may be useful planning tool of process improvement based on PDCA cycle that is an interative, four- stage approach for continually improving. The article contains precise diagnosis of internal and external environment of the chosen service enterprise and the choice of the most matching strategy that could maximize strength, reduce weaknesses, take advantages of opportunities or minimize threats.
\end{abstract}

Keywords: continuous improvement, PDCA cycle, planning, strategy, SWOT-TOWS analysis

\section{Introduction}

Process improvement is a necessary action that companies are forced to realize if they want to perform a duty and develop for keeping them competitive. There are a number of various definition of improvement. According to the most common one process improvement can be defined as a proactive task of identifying, analyzing and improving current business processes within the enterprise for optimization and achieving new standards (PLURA J. 2000). There are different approaches to be considered because process improvement should involve a specific methodology that would focus on indicated areas of improvement and use the most useful methods and tools to achieve the expected results.

\section{Planning process improving based on PDCA cycle}

The PDCA cycle, also known as the Deming cycle, is an interative four-step method of continual improvement of processes, products or services. The stages of the PDCA are interpreted as follows (Fig. 1) (MARUTA R. 2012):

- Plan - determine objetive that you want to be reached and methods and tools to achieve it,

\footnotetext{
${ }^{1}$ Eng., Czestochowa University of Technology, Faculty of Management, Student Association „Promotor Jakości”, e-mail: kamilakowalik93@gmail.com

${ }^{2}$ PhD., Eng., Czestochowa University of Technology, Faculty of Management, Department of Production Engineering and Safety, e-mail: klimt@ wip.pcz.pl
} 
- Do - implement what have been planned, according to intentions, remember about collecting the data for further steps;

- Check - if the expectations were accomplished; control the effects; examine achieved results;

- Act - adopt the successful methods, enact new standards for the organization.

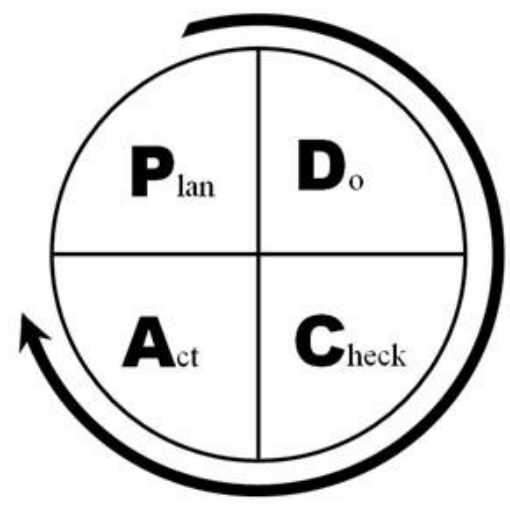

Fig. 1. PDCA cycle.

Source: http://www.workspacetraining.com.au/lesson1_pdca_cycle.html

The key point is that this circle goes round and round because the iteration is the fundamental principle of the Deming wheel. Each stage of the PDCA cycle should be considered and realized based on definited, useful tools and methods.

Planning, the first stage of the process improving, includes description of the current situation of the enterprise and its environment, identification of the problems, prioritizing and decision making. The most widespread tool used for characterization of internal and external environment is SWOT analysis.

\section{Theoretical framework of SWOT-TOWS analysis}

The SWOT analysis is one of the most prevalent method used in management to create strategy. The name of this tool is an acronym of strength, weakness, opportunities and threats as the main factors of internal ( $\mathrm{S}$ and $\mathrm{W})$ and external $(\mathrm{O}$ and $\mathrm{T})$ environment of the enterprise that are analyzed. Internal factors are likely to be controlled by the company but the external ones, although their equal importance and huge influence on the organization, could be only monitored. The ultimate goal of this analysis is a choice of the most matching strategy that allow the enterprise to perform the duty and develop with respect to the interaction between its internal and external environment (ORESKI D. 2012). 
The analysis contains several basic steps. The first one is to identify the strengths and weaknesses of the enterprise and the opportunities and threats in its environment. The strength is defined as the factor which contributes to the realization of enterprise's mission that is identified in any internal asset such as: resource, staff, management and knowledge. The weakness is a condition that threatens the organization's position or functioning. The opportunity means the chance that in case of being taken advantage of, helps to achieve the goals. The last one is the threat-the unfavorable trend that could have the negative effect if there would not be taken any corrective actions (DYSON R.G. 2004).

The second step contains checking the interaction between the internal and external factors (whether the strong points allow using the chances and can reduce the threats and whether the weaknesses limit the opportunities and strengthen the dangers). This part of study is the most often presented in the tables with the particular factors' weights and ranks. The result of each table should be the sum of interaction and the sum of products between the chosen factors.

The supplement, closely related to SWOT is TOWS analysis. According to its author, the factors should be studied in different order such as: first the external factors (threats and opportunities) and then the internal ones (weaknesses and strengths). It is based on a conviction that the position of the organization is divided into the external environment that has specified (positive or negative) impact on it.

The choice of strategy is the result of SWOT-TOWS analysis. Based on a weighted average number of interaction, alternative strategies are combinations of the four factors: aggressive strategy (aims using the strong points to take advantage of the chances), conservative strategy (considers the strengths to avoid the dangers), competitive strategy (that overcomes weaknesses by using the chances) and defensive strategy (acts for minimizing weaknesses and avoiding the threats) (GOMATESH M., POORNIMA M. 2012).

\section{SWOT-TOWS analysis of the chosen service enterprise}

The first stage of SWOT analysis is an identification of the internal and external factors and their importance. The analyzed service enterprise - the chosen cinema belongs to the network of dominant cinema operator in this area of Europe. This feature and the lack of competition in the city are the most important strengths. For the weakest factors were considered features such as rising prices of services (which grew three times during one year) and old building and equipment. In contrast, there are lot of identified opportunities such as continuous development of cinema technology, actions against movie piracy and improving the material situation of society caused by 
pro-family government programs. It is also worth mentioning about the biggest dangers of the external environment that are the possibility of the emergence of new competition and development of the RTV equipment technology.

Strengths, weaknesses, opportunities and threats along with their weights are presented in table 1.

Table 1. SWOT factors and their validity

\begin{tabular}{|c|c|c|c|}
\hline The internal factors & Weight & The internal factors & Weight \\
\hline Strengths & 1 & Weaknesses & 1 \\
\hline good localization [S1] & 0.15 & \multirow{2}{*}{$\begin{array}{l}\text { lack of cooperation with cultur- } \\
\text { al institution and schools [W1] }\end{array}$} & \multirow{2}{*}{0.2} \\
\hline lack of competition [S2] & 0.2 & & \\
\hline \multirow{2}{*}{$\begin{array}{c}\text { belonging to the network of the dominant } \\
\text { cinema operator in Eastern and Central } \\
\text { Europe [S3] }\end{array}$} & \multirow{2}{*}{0.2} & rising prices of services [W2] & 0.3 \\
\hline & & \multirow{2}{*}{$\begin{array}{l}\text { high turnover of employees } \\
\text { [W3] }\end{array}$} & \multirow{2}{*}{0.2} \\
\hline good financial situation [S4] & 0.15 & & \\
\hline highly skilled workers [S5] & 0.1 & \multirow{3}{*}{$\begin{array}{l}\text { lack of modernization of the } \\
\text { exuipment and the building } \\
\text { [W4] }\end{array}$} & \multirow{3}{*}{0.3} \\
\hline extensive service offer [S6] & 0.1 & & \\
\hline good spatial conditions of the building [S7] & 0.1 & & \\
\hline The external factors & Weight & The external factors & Weight \\
\hline Opportunities & 1 & Threats & 1 \\
\hline \multirow{2}{*}{ development grants [O1] } & \multirow{2}{*}{0.1} & economic crisis $[\mathrm{T} 1]$ & 0.2 \\
\hline & & \multirow{2}{*}{$\begin{array}{l}\text { the possibility of the emergence } \\
\text { of new competition [T2] }\end{array}$} & \multirow{2}{*}{0.3} \\
\hline the increase of request for culture $[\mathrm{O} 2]$ & 0.1 & & \\
\hline revitalization of regional economy [O3] & 0.1 & \multirow{3}{*}{$\begin{array}{l}\text { development of the rtv equip- } \\
\text { ment technology [T3] }\end{array}$} & \multirow{3}{*}{0.3} \\
\hline $\begin{array}{l}\text { improving the material situation of society } \\
{[\mathrm{O} 4]}\end{array}$ & 0.2 & & \\
\hline $\begin{array}{l}\text { the possibility of becoming the entertain- } \\
\text { ment center in the city [O5] }\end{array}$ & 0.1 & & \\
\hline development of cinema technology [O6] & 0.2 & \multirow{2}{*}{$\begin{array}{l}\text { increasing interest of Internet } \\
\text { movie rentals [T4] }\end{array}$} & \multirow{2}{*}{0.2} \\
\hline tightening of action against piracy [O7] & 0.2 & & \\
\hline
\end{tabular}

Source: own study

Next step is to analyze the relationship between four groups of factors: whether the particular strong point allows using the given chance, can reduce the danger and whether the particular weakness limits the ability to use the chance or strengthens the threat. The tables contain factors, weights (W), number of interactions (No. I), prod- 
uct weight and interactions (P) and Rank (R). Tables 2 to 5 present the analysis of the linkages between factors.

Table 2. Whether a particular strong point allows using the given chance?

\begin{tabular}{|c|c|c|c|c|c|c|c|c|c|c|c|}
\hline $\begin{array}{c}\text { Opportunits/ } \\
\text { strengths }\end{array}$ & $\mathbf{O 1}$ & $\mathbf{O 2}$ & $\mathbf{O 3}$ & $\mathbf{O 4}$ & $\mathbf{O 5}$ & $\mathbf{O 6}$ & $\mathbf{O 7}$ & $\mathbf{W}$ & $\begin{array}{c}\text { No. } \\
\text { I }\end{array}$ & $\mathbf{P}$ & $\mathbf{R}$ \\
\hline S1 & 1 & 1 & 0 & 0 & 1 & 0 & 0 & 0.15 & 3 & 0.45 & 3 \\
\hline S2 & 1 & 1 & 1 & 1 & 1 & 0 & 0 & 0.2 & 5 & 1 & 1 \\
\hline S3 & 0 & 1 & 0 & 0 & 1 & 1 & 0 & 0.2 & 3 & 0.6 & 2 \\
\hline S4 & 1 & 0 & 0 & 0 & 1 & 1 & 0 & 0.15 & 3 & 0.45 & 3 \\
\hline S5 & 1 & 0 & 0 & 0 & 1 & 0 & 0 & 0.1 & 2 & 0.2 & 7 \\
\hline S6 & 1 & 1 & 0 & 1 & 1 & 0 & 0 & 0.1 & 4 & 0.4 & 5 \\
\hline S7 & 1 & 0 & 0 & 0 & 1 & 1 & 0 & 0.1 & 3 & 0.3 & 6 \\
\hline W & 0.1 & 0.1 & 0.1 & 0.2 & 0.1 & 0.2 & 0.2 & & & & \\
\hline No. I & 6 & 4 & 1 & 2 & 7 & 3 & 0 & & & & \\
\hline P & 0.6 & 0.4 & 0.1 & 0.4 & 0.7 & 0.6 & 0 & & & & \\
\hline R & 2 & 4 & 6 & 4 & 1 & 2 & 7 & & & & \\
\hline $\begin{array}{c}\text { The sum of } \\
\text { interaction }\end{array}$ & & & & & & & & & $\mathbf{4 6}$ & & \\
\hline $\begin{array}{c}\text { The sum of } \\
\text { products }\end{array}$ & & & & & & & & & & $\mathbf{6 . 2}$ & \\
\hline
\end{tabular}

Source: own study

The sum of interaction and the sum of products is the biggest in table 2. It means that the enterprise has a lot of chances that could be used because of its strong points. The most interactions with the opportunities has factor S2. The lack of competition is the key point which could cause a lot of financial profits to the cinema in case of improving the material situation of society, developing of cinema technology and tightening the actions against piracy. Table 3 contains the possibility of reducing the threats by enterprise's strong points. The sum of interaction and the sum of products is there the lowest which means that the strengths influence on dangers couldn't help the enterprise the most in the importing.

The relation between factors such as the weak points and chances is presented in table 4 . The sum of interaction is 12 while the sum of products is 2,3 which is the second of the lowest in SWOT analysis. The most important weakness is lack of cooperation with cultural institution and schools that could restrain even 3 opportunities.

Table 4 contains the association between weaknesses and threats. The sum of interaction is 14 and the sum of products is 3,7- the second of the biggest. It means that 
the weaknesses have big influence on the dangers which could be strengthen. The weakness W3 - high turnover of employees might increase four threats.

Table 3. Whether a particular strong point can reduce the threat?

\begin{tabular}{|c|c|c|c|c|c|c|c|c|}
\hline $\begin{array}{c}\text { Threats/ } \\
\text { Strengths }\end{array}$ & T1 & T2 & T3 & T4 & W & No. I & P & R \\
\hline S1 & 0 & 0 & 0 & 0 & 0.15 & 0 & 0 & 3 \\
\hline S2 & 0 & 0 & 0 & 0 & 0.2 & 0 & 0 & 3 \\
\hline S3 & 0 & 1 & 0 & 1 & 0.2 & 2 & 0.4 & 1 \\
\hline S4 & 0 & 0 & 0 & 0 & 0.15 & 0 & 0 & 3 \\
\hline S5 & 0 & 0 & 0 & 0 & 0.1 & 0 & 0 & 3 \\
\hline S6 & 0 & 1 & 1 & 1 & 0.1 & 3 & 0.3 & 2 \\
\hline S7 & 0 & 0 & 0 & 0 & 0.1 & 0 & 0 & 3 \\
\hline W & 0.2 & 0.3 & 0.3 & 0.2 & & & & \\
\hline No. I & 0 & 2 & 1 & 2 & & & & \\
\hline P & 0 & 0.6 & 0.3 & 0.4 & & & & \\
\hline R & 4 & 1 & 3 & 2 & & & & \\
\hline $\begin{array}{c}\text { The sum of } \\
\text { interaction }\end{array}$ & & & & & & $\mathbf{1 0}$ & & \\
\hline $\begin{array}{c}\text { The sum of } \\
\text { products }\end{array}$ & & & & & & & $\mathbf{2}$ & \\
\hline
\end{tabular}

Source: own study

Table 4. Whether a particular weakness limits the ability to use the chance?

\begin{tabular}{|c|c|c|c|c|c|c|c|c|c|c|c|}
\hline $\begin{array}{c}\text { Opportunits/ } \\
\text { Weaknesses }\end{array}$ & $\mathbf{O 1}$ & $\mathbf{O 2}$ & $\mathbf{O 3}$ & $\mathbf{O 4}$ & $\mathbf{O 5}$ & $\mathbf{O 6}$ & $\mathbf{O 7}$ & $\mathbf{W}$ & $\begin{array}{c}\text { No. } \\
\text { I }\end{array}$ & $\mathbf{P}$ & $\mathbf{R}$ \\
\hline W1 & 1 & 0 & 0 & 1 & 1 & 0 & 0 & 0.2 & 3 & 0.6 & 1 \\
\hline W2 & 0 & 1 & 0 & 0 & 1 & 0 & 0 & 0.3 & 2 & 0.6 & 1 \\
\hline W3 & 0 & 0 & 0 & 0 & 0 & 0 & 0 & 0.2 & 0 & 0 & 4 \\
\hline W4 & 0 & 0 & 0 & 0 & 1 & 0 & 0 & 0.3 & 1 & 0.3 & 3 \\
\hline W & 0.1 & 0.1 & 0.1 & 0.2 & 0.1 & 0.2 & 0.2 & & & & \\
\hline No. I & 1 & 1 & 0 & 1 & 3 & 0 & 0 & & & & \\
\hline P & 0.2 & 0.1 & 0 & 0.2 & 0.3 & 0 & 0 & & & & \\
\hline R & 2 & 4 & 5 & 2 & 1 & 5 & 5 & & & & \\
\hline $\begin{array}{c}\text { The sum of } \\
\text { interaction }\end{array}$ & & & & & & & & & $\mathbf{1 2}$ & & \\
\hline $\begin{array}{c}\text { The sum of } \\
\text { products }\end{array}$ & & & & & & & & & & $\mathbf{2 . 3}$ & \\
\hline
\end{tabular}

Source: own study 
Quality. Production. Improvement

Table 4. Whether a particular weakness strenghtens the threat?

\begin{tabular}{|c|c|c|c|c|c|c|c|c|}
\hline $\begin{array}{c}\text { Threats/ } \\
\text { Weaknesses }\end{array}$ & T1 & T2 & T3 & T4 & W & $\begin{array}{c}\text { No. } \\
\text { I }\end{array}$ & P & R \\
\hline W1 & 0 & 1 & 0 & 1 & 0.2 & 2 & 0.4 & 3 \\
\hline W2 & 0 & 1 & 1 & 1 & 0.3 & 3 & 0.9 & 1 \\
\hline W3 & 0 & 0 & 0 & 0 & 0.2 & 0 & 0 & 4 \\
\hline W4 & 0 & 1 & 0 & 1 & 0.3 & 2 & 0.6 & 2 \\
\hline W & 0.2 & 0.3 & 0.3 & 0.2 & & & & \\
\hline No. I & 0 & 3 & 1 & 3 & & & & \\
\hline P & 0 & 0.9 & 0.3 & 0.6 & & & & \\
\hline R & 4 & 1 & 3 & 2 & & & & \\
\hline $\begin{array}{c}\text { The sum of } \\
\text { interaction }\end{array}$ & & & & & & $\mathbf{1 4}$ & & \\
\hline $\begin{array}{c}\text { The sum of } \\
\text { products }\end{array}$ & & & & & & & $\mathbf{3 . 7}$ & \\
\hline
\end{tabular}

Source: own study

The next part of the study is TOWS analysis. It could show other important relationships which couldn't have been presented in SWOT analysis. Tables 5 to 8 contain number and products of TOWS interaction.

Table 5. Whether a particular opportunity increases the strong point?

\begin{tabular}{|c|c|c|c|c|c|c|c|c|c|c|c|}
\hline $\begin{array}{c}\text { Opportunities/ } \\
\text { Strengths }\end{array}$ & S1 & S2 & S3 & S4 & S5 & S6 & S7 & W & $\begin{array}{c}\text { No. } \\
\text { I }\end{array}$ & P & R \\
\hline O1 & 1 & 0 & 0 & 0 & 0 & 1 & 0 & 0.1 & 2 & 0.2 & 6 \\
\hline O2 & 1 & 1 & 0 & 1 & 0 & 1 & 0 & 0.1 & 4 & 0.4 & 4 \\
\hline O3 & 0 & 0 & 0 & 1 & 1 & 1 & 0 & 0.1 & 3 & 0.3 & 5 \\
\hline O4 & 0 & 0 & 0 & 1 & 1 & 1 & 0 & 0.2 & 3 & 0.6 & 1 \\
\hline O5 & 1 & 1 & 1 & 1 & 0 & 1 & 1 & 0.1 & 5 & 0.5 & 3 \\
\hline O6 & 0 & 0 & 1 & 1 & 0 & 1 & 0 & 0.2 & 3 & 0.6 & 1 \\
\hline O7 & 0 & 0 & 0 & 1 & 0 & 0 & 0 & 0.2 & 1 & 0.2 & 6 \\
\hline W & 0.15 & 0.2 & 0.2 & 0.15 & 0.1 & 0.1 & 0.1 & & & & \\
\hline No. I & 3 & 2 & 2 & 6 & 2 & 6 & 1 & & & & \\
\hline P & 0.45 & 0.4 & 0.4 & 0.9 & 0.2 & 0.6 & 0.1 & & & & \\
\hline R & 3 & 4 & 4 & 1 & 6 & 2 & 7 & & & & \\
\hline $\begin{array}{c}\text { The sum of } \\
\text { interaction }\end{array}$ & & & & & & & & & $\mathbf{4 3}$ & & \\
\hline $\begin{array}{c}\text { The sum of } \\
\text { products }\end{array}$ & & & & & & & & & & $\mathbf{5 . 8 5}$ & \\
\hline
\end{tabular}

Source: own study 
Table 5 presents the opportunities influence on the strong points. The sum of interaction is 43 which is the biggest number but the sum of products $(5,85)$ is the second result of the TOWS analysis. It means that there is a strong, positive connection between strengths and opportunities that could strengthen the enterprise. Most interaction with the strong points has the fifth chance (O5) - the possibility of becoming the entertainment center in the city which increases five strong points.

Table 6 shows how threats can limit the strengths. There is the lowest connection between these factors, only 13 of the sum of interaction and 2,4 of the sum of products. The most dangerous threat is $\mathrm{T} 1$ - economic crisis that limits three strong points such as financial situation, skilled workers and extensive service offer.

In table 7 there is presented the possibility of reducing the weaknesses by the chances. The sum of interaction is the second of the biggest in TOWS analysis - 34 but the sum of products is the highest. It means that the opportunities from external environment of the cinema can reduce the weak point. There is one chance- development grants that can limit all the weaknesses and other three opportunities have the influence on even three weak points.

The last table (table 8) contains the interaction between threats and weaknesses. It shows whether the danger can strengthen the weakness. The relationship there is low so there is an expectation that threats are notas dangerous as they could be.

Based on presented data, table 9 contains the aggregate results of the SWOT and TOWS analysis with the sums of interaction and products for all connected factors.

Table 6. Whether a particular threat limits the strength?

\begin{tabular}{|c|c|c|c|c|c|c|c|c|c|c|c|}
\hline $\begin{array}{c}\text { Strength/ } \\
\text { Threats }\end{array}$ & S1 & S2 & S3 & S4 & S5 & S6 & S7 & W & $\begin{array}{c}\text { No. } \\
\text { I }\end{array}$ & P & R \\
\hline T1 & 0 & 0 & 0 & 1 & 1 & 1 & 0 & 0.2 & 3 & 0.6 & 1 \\
\hline T2 & 0 & 1 & 0 & 1 & 0 & 0 & 0 & 0.3 & 1 & 0.3 & 2 \\
\hline T3 & 0 & 0 & 0 & 1 & 0 & 0 & 0 & 0.3 & 1 & 0.3 & 2 \\
\hline T4 & 0 & 0 & 0 & 1 & 0 & 0 & 0 & 0.2 & 1 & 0.2 & 4 \\
\hline W & 0.15 & 0.2 & 0.2 & 0.15 & 0.1 & 0.1 & 0.1 & & & & \\
\hline No. I & 0 & 1 & 0 & 4 & 1 & 1 & 0 & & & & \\
\hline P & 0 & 0.2 & 0 & 0.6 & 0.1 & 0.1 & 0 & & & & \\
\hline R & 5 & 2 & 5 & 1 & 3 & 3 & 5 & & & & \\
\hline $\begin{array}{c}\text { The sum of } \\
\text { interaction }\end{array}$ & & & & & & & & & $\mathbf{1 3}$ & & \\
\hline $\begin{array}{c}\text { The sum of } \\
\text { products }\end{array}$ & & & & & & & & & & $\mathbf{2 . 4}$ & \\
\hline
\end{tabular}

Source: own study 
Quality. Production. Improvement

Table 7. Whether a particular chance can reduce the weakness?

\begin{tabular}{|c|c|c|c|c|c|c|c|c|}
\hline $\begin{array}{c}\text { Weaknesses/ } \\
\text { Opportunities }\end{array}$ & W1 & W2 & W3 & W4 & W & No. I & P & R \\
\hline O1 & 1 & 1 & 1 & 1 & 0.1 & 4 & 0.4 & 2 \\
\hline O2 & 1 & 1 & 0 & 0 & 0.1 & 2 & 0.2 & 5 \\
\hline O3 & 1 & 1 & 0 & 0 & 0.1 & 2 & 0.2 & 5 \\
\hline $\mathbf{O 4}$ & 1 & 1 & 0 & 0 & 0.2 & 2 & 0.4 & 2 \\
\hline $\mathbf{O 5}$ & 1 & 1 & 0 & 1 & 0.1 & 3 & 0.3 & 4 \\
\hline $\mathbf{O 6}$ & 1 & 1 & 0 & 1 & 0.2 & 3 & 0.6 & 1 \\
\hline $\mathbf{O 7}$ & 0 & 0 & 0 & 1 & 0.2 & 1 & 0.2 & 5 \\
\hline $\mathbf{W}$ & 0.2 & 0.3 & 0.2 & 0.3 & & & & \\
\hline No. I & 6 & 6 & 1 & 4 & & & & \\
\hline $\mathbf{P}$ & 1.2 & 1.8 & 0.2 & 1.2 & & & & \\
\hline $\mathbf{R}$ & 2 & 1 & 4 & 2 & & & & \\
\hline $\begin{array}{c}\text { The sum of } \\
\text { interaction }\end{array}$ & & & & & & $\mathbf{3 4}$ & & \\
\hline $\begin{array}{c}\text { The sum of } \\
\text { products }\end{array}$ & & & & & & & $\mathbf{6 . 7}$ & \\
\hline
\end{tabular}

Source: own study

Table 8. Whether a particular threat strengthens the weakness?

\begin{tabular}{|c|c|c|c|c|c|c|c|c|}
\hline $\begin{array}{c}\text { Threats/ } \\
\text { Weaknesses }\end{array}$ & W1 & W2 & W3 & W4 & W & No. I & P & R \\
\hline T1 & 1 & 1 & 1 & 1 & 0.2 & 4 & 0.8 & 1 \\
\hline T2 & 0 & 0 & 0 & 0 & 0.3 & 0 & 0 & 4 \\
\hline T3 & 1 & 1 & 0 & 0 & 0.3 & 2 & 0.6 & 2 \\
\hline T4 & 1 & 0 & 0 & 0 & 0.2 & 1 & 0.2 & 3 \\
\hline W & 0.2 & 0.3 & 0.2 & 0.3 & & & & \\
\hline No. I & 3 & 2 & 1 & 1 & & & & \\
\hline P & 0.6 & 0.6 & 0.2 & 0.3 & & & & \\
\hline R & 1 & 1 & 4 & 3 & & & & \\
\hline $\begin{array}{c}\text { The sum of } \\
\text { interaction }\end{array}$ & & & & & & $\mathbf{1 4}$ & & \\
\hline $\begin{array}{c}\text { The sum of } \\
\text { products }\end{array}$ & & & & & & & $\mathbf{3 . 3}$ & \\
\hline
\end{tabular}

Source: own study 
Table 9. Results of SWOT and TOWS analysis

\begin{tabular}{|c|c|c|c|c|c|c|}
\hline & \multicolumn{2}{|c|}{$\begin{array}{c}\text { Results of SWOT } \\
\text { analysis }\end{array}$} & \multicolumn{2}{c|}{$\begin{array}{c}\text { Results of TOWS } \\
\text { analysis }\end{array}$} & \multicolumn{2}{|c|}{$\begin{array}{c}\text { Summary SWOT/ } \\
\text { TOWS results }\end{array}$} \\
\hline \multirow{2}{*}{ Factors } & $\begin{array}{c}\text { The sum } \\
\text { of inte- } \\
\text { raction }\end{array}$ & $\begin{array}{c}\text { The } \\
\text { sum of } \\
\text { pro- } \\
\text { ducts }\end{array}$ & $\begin{array}{c}\text { The sum } \\
\text { of inter- } \\
\text { action }\end{array}$ & $\begin{array}{c}\text { The } \\
\text { sum of } \\
\text { prod- } \\
\text { ucts }\end{array}$ & $\begin{array}{c}\text { The sum } \\
\text { of inter- } \\
\text { action }\end{array}$ & $\begin{array}{c}\text { The sum } \\
\text { of prod- } \\
\text { ucts }\end{array}$ \\
\hline S/ O & 46 & 6.2 & 43 & 5.85 & 89 & 12.05 \\
\hline S/ T & 10 & 2 & 13 & 2.4 & 23 & 4.4 \\
\hline W/O & 12 & 2.3 & 34 & 6.7 & 46 & 8.9 \\
\hline W/Z & 14 & 3.7 & 14 & 3.3 & 28 & 7 \\
\hline
\end{tabular}

Source: own study

Strategy for the service enterprise- the chosen cinema, has been determined based on certain factors and their impact strength. The results of the SWOT/TOWS analysis and the choice of the best way of action is presented in table 10 .

From the data in table 10 shows that enterprise should choose aggressive strategy because of its the best result. It means that in its internal environment strengths predominate over the weaknesses and in the external one- opportunities over the threats.

Aggressive strategy involves the maximum use of the chances and strengths in order to develop dynamically.

Table 10. Results of SWOT and TOWS analysis

\begin{tabular}{|c|c|c|}
\hline \multirow{4}{*}{ Strengths } & Opportunities & Threats \\
\cline { 2 - 3 } & Aggressive strategy & Conservative strategy \\
\cline { 2 - 3 } & The number of interaction & The number of interaction \\
& 89 & 23 \\
\hline \multirow{4}{*}{ Weaknesses } & $\begin{array}{c}\text { Weighted average number } \\
\text { of interaction }\end{array}$ & $\begin{array}{c}\text { Weighted average number } \\
\text { of interaction }\end{array}$ \\
& 12.05 & 4.4 \\
\cline { 2 - 3 } & Competitive strategy & Defensive strategy \\
\cline { 2 - 3 } & The number of interaction & The number of interaction \\
& 46 & 28 \\
\hline & Weighted average number & Weighted average number \\
& of interaction & 7 \\
\hline
\end{tabular}

Source: own work 
In case of planning the process' improving, SWOT-TOWS analysis contribute to characterization of current situation of the enterprise and its environment as a fundamental action of further planning steps.

\section{Summary}

Summing up the issues presented in the paper, continuous improving of the processes is very important action that should be a part of each service enterprise functioning includes cultural and entertainment companies such as the cinemas. The most widespread and overall method of improving is PDCA cycle- the wheel of interactive amending. Plan-do-check-act actions should be realized with using effective tools. The first of them- planning, starts with precise diagnosis of internal and external environment that is the basis for further steps. The used tool- SWOT-TOWS analysis shows that the analyzed service enterprise- one of the cinema belonging to famous cinema operator is in the situation that any organization would like to be. By having many important strong points it can take advantage of a lot of identified opportunities. It means that this enterprise has huge possibility of process improving and further steps of planning and other stages should be realized.

\section{Bibliography}

1. DYSON R.G. 2004. Strategic development and SWOT analysis at the University of Warwick. „European Journal of Operational Research”, No 152.

2. GOMATESH M., POORNIMA M. 2012. Strategic formulation using TOWS matrix-a case study. ,International Journal of Research and Development”, Vol. 1, No 1.

3. MARUTA R. 2012. Maximizing Knowledge Work Productivity: A Time Constrained and Activity Visualizes PDCA cycle. „Knowledge and Process Management”, vol. 4, no 19.

4. ORESKI D. 2012. Strategy Development by using SWOT-AHP. „TEM Journal”, Vol. 1, No 4.

5. PluRA J. 2000. Continual improvement within the quality management systems. „Kvalita Inovacia Prospetita", no 4/1. 